\title{
Fingolimod Rescues Memory and Improves Pathological Hallmarks in the 3xTg-AD Model of Alzheimer's Disease
}

\author{
Steven G. Fagan ${ }^{1} \cdot$ Sibylle Bechet ${ }^{1} \cdot$ Kumlesh K. Dev ${ }^{1}$
}

Received: 24 May 2021 / Accepted: 19 October 2021 / Published online: 15 January 2022

(C) The Author(s) 2022

\begin{abstract}
Therapeutic strategies for Alzheimer's disease (AD) have largely focused on the regulation of amyloid pathology while those targeting tau pathology, and inflammatory mechanisms are less explored. In this regard, drugs with multimodal and concurrent targeting of $\mathrm{A} \beta$, tau, and inflammatory processes may offer advantages. Here, we investigate one such candidate drug in the triple transgenic 3xTg-AD mouse model of $\mathrm{AD}$, namely the disease-modifying oral neuroimmunomodulatory therapeutic used in patients with multiple sclerosis, called fingolimod. In this study, administration of fingolimod was initiated after behavioral symptoms are known to emerge, at 6 months of age. Treatment continued to 12 months when behavioral tests were performed and thereafter histological and biochemical analysis was conducted on postmortem tissue. The results demonstrate that fingolimod reverses deficits in spatial working memory at 8 and 12 months of age as measured by novel object location and Morris water maze tests. Inflammation in the brain is alleviated as demonstrated by reduced Iba1-positive and CD3-positive cell number, less ramified microglial morphology, and improved cytokine profile. Finally, treatment with fingolimod was shown to reduce phosphorylated tau and APP levels in the hippocampus and cortex. These results highlight the potential of fingolimod as a multimodal therapeutic for the treatment of AD.
\end{abstract}

Keywords Alzheimer's disease $\cdot$ FTY720 $\cdot$ Sphingosine-1-phosphate $\cdot$ Inflammation

$\begin{array}{ll}\text { Abbreviations } \\ \text { AD } & \text { Alzheimer's disease } \\ \text { A } \beta & \text { Amyloid-beta } \\ \text { APP } & \text { Amyloid precursor protein } \\ \text { FTY720 } & \text { Fingolimod, Gilenya } \\ \text { S1P } & \text { Spingosine-1-phosphate } \\ \text { CNS } & \text { Central nervous system } \\ \text { 3xTg-AD } & \text { B6;1239-Tg(APPSwe,tauP301L)1Lfa } \\ & \text { Psen1 } 1^{\text {tm1Mm }} \text { mice } \\ \text { WT } & \text { Wild-type mice } \\ \text { NOL } & \text { Novel object location } \\ \text { MWM } & \text { Morris water maze }\end{array}$

Steven G. Fagan

stevenfagan@ rcsi.com

Kumlesh K. Dev

devk@tcd.ie

1 Drug Development, School of Medicine, Trinity College Dublin, Dublin, Ireland

\section{Introduction}

Alzheimer's disease (AD) is an age-related neurodegenerative condition and the most common form of dementia which affects approximately 44 million people worldwide [55]. Symptoms of AD include the progressive loss of memory and cognition resulting in a dependency on full-time care [4]. Current treatments, including cholinesterase inhibitors and N-methyl-D-aspartate receptor antagonists, aim to improve symptom severity but do not affect the course of the disease [76]. With an increasingly aged global population and ongoing failures in drug discovery efforts, the burden of $\mathrm{AD}$ and other dementias are a serious concern for healthcare systems worldwide $[49,55]$.

The characteristic hallmarks of AD include the development of extracellular amyloid plaques and intracellular neurofibrillary tangles [21]. Amyloid plaques form through the aggregation of amyloid- $\beta(\mathrm{A} \beta)$, a cleaved product of the amyloid precursor protein (APP) [71]. Mutations to genes encoding APP and the enzymes that cleave APP have been implicated in a small number of AD cases and are regularly used as the basis for animal models [73]. Neurofibrillary tangles are intracellular aggregates of 
hyperphosphorylated tau. Under pathological conditions tau becomes phosphorylated (phospho-tau), insoluble and aggregates, forming tangles [73]. Mutations to the MAPT gene that encodes tau have been implicated in the development of dementia and increased phosphorylation at positions Ser-396, Ser-400, Thr-403, and Ser-404 [1].

Inflammation in the central nervous system (CNS) has emerged as a key driver in the development of $\mathrm{AD}$ [33]. Postmortem analyses have determined a significant upregulation in activated microglia and inflammatory markers in the brains of AD patients, and recent imaging studies have used microglial activation in combination with tau localization as a measure of cognitive decline [46-48, 70]. Previous epidemiological data indicated a reduced risk of developing $\mathrm{AD}$ among people receiving NSAID treatment, however, more recent studies have demonstrated that anti-inflammatory drugs alone are insufficient $[68,79]$. Increasing evidence has implicated the peripheral immune response in AD pathology where $\mathrm{T}$ cell responses specific to $\mathrm{A} \beta$ have been observed in blood from AD patients, as has T-cell infiltration in the brains of $\mathrm{AD}$ patients where they surround $\mathrm{A} \beta$ and tau pathology [51, 52].

Given current failures in therapies for $\mathrm{AD}$, approaches with multimodal targeting of inflammatory and neuronal systems may be worthy of consideration. One such candidate drug is fingolimod (FTY720, Gilenya ${ }^{\circledR}$ ), the disease-modifying oral neuroimmunomodulatory therapeutic used in multiple sclerosis and that has been investigated in a number of neurodegenerative diseases [57]. Fingolimod readily passes the blood-brain barrier and when phosphorylated binds to sphingosine-1-phosphate (S1P) receptors $\left(\mathrm{S}_{1} \mathrm{P}_{1-5}\right)$, except for $\mathrm{S}_{1} \mathrm{P}_{2}[10,50]$. $\mathrm{S} 1 \mathrm{P}$ receptors are G-protein coupled and expressed in many cell types including the immune system and central nervous system. The canonical therapeutic activity of fingolimod arises from its retention of $\mathrm{T}$ cells in lymphoid organs, where it binds $\mathrm{S}_{1} \mathrm{P}_{1}$ on $\mathrm{T}$ cells causing receptor internalization thereby inhibiting the S1P-mediated egress of T cells into the blood [9]. We and others have now shown that fingolimod can target $\mathrm{S} 1 \mathrm{P}$ receptors expressed on neuronal and glial cells, where they can regulate neurogenesis, neurite outgrowth, myelination, inflammation, astrogliosis, and migration $[22,31,54$, $56-58,60,63,65,66]$.

In $\mathrm{AD}$, the $\mathrm{S} 1 \mathrm{P}$ system is altered with a reduction in sphingosine kinase- 1 and -2 , and an increase in sphingosine lyase associated with advancing Braak stages [15, 20, 38]. Furthermore, a progressive decline in S1P is also observed throughout the course of the disease [20]. Previous studies have shown that fingolimod can reduce the production of $\mathrm{A} \beta, \gamma$-secretase activity, and the formation of amyloid plaques in vitro and in vivo [7, 72]. Furthermore, presymptomatic administration of fingolimod has been shown to prevent cognitive decline and reduce the severity of CNS inflammation [7, 12].

For this study, we utilized the $3 \times \mathrm{Tg}-\mathrm{AD}$ mouse model of AD which displays cognitive impairment from 3 months, develops amyloid plaques and CNS inflammation from 6 months, and neurofibrillary tangles of phospho-tau emerge from 12 months of age. Oral administration of fingolimod began after the onset of symptoms, at 6 months, and continued until 12 months of age. Previous studies have demonstrated the preventative effects of fingolimod in models of AD; this study indicates that the beneficial effects of fingolimod are also apparent in older mice with developed pathologies. Treatment with fingolimod rescues memory impairment and reduces inflammation in the CNS. Furthermore, we have demonstrated for the first time that fingolimod reduces tau phosphorylation and APP expression in 3xTg-AD mice.

\section{Methods}

\section{Animals}

Male B6;129-Tg(APPSwe, tauP301L)1Lfa Psen $1^{\text {tm1Mpm }}$ mice $(3 \times T g-A D$; stock 004,807) and B6129SF2 wild-type controls (WT; stock 101,045) were purchased from Jackson Laboratories. An increasing body of work has demonstrated greater $\mathrm{A} \beta$ pathology in female $3 \mathrm{xTg}-\mathrm{AD}$ mice $[27,30,53]$ and conflicting reports exist on sexual dimorphic tau burden $[30,35,53,77]$. No difference in working memory has been found between male and female $3 \times \mathrm{Tg}-\mathrm{AD}$ mice [19], and male $3 \times \mathrm{Tg}-\mathrm{AD}$ have been shown to perform worse at spatial memory tasks [69]. Furthermore, a more pronounced alteration in the immune system has been reported in male $3 \times \operatorname{Tg}-\mathrm{AD}$ mice $[5,29,39]$. Given the immunomodulatory mechanisms of fingolimod and inflammation being of primary focus to this study male, 3xTg-AD mice were chosen for this study. Mice were age-matched and housed under standard conditions $\left(22 \pm 2{ }^{\circ} \mathrm{C}, 12: 12 \mathrm{~h}\right.$ light:dark cycle, food and water ad libitum). Experiments were carried out under institutional and governmental guidelines.

\section{Treatment}

From 6-12 months of age fingolimod (Caymen Chemical \#10,006,292 $1 \mathrm{mg} / \mathrm{kg} /$ day) was administered via the drinking water. At 8 and 12 months, blood was drawn from the submandibular vein for lymphocyte count (Sysmex KX-21 blood analyzer) and fluorescent activated cell sorting (FACS) analysis. At 12 months animals were sacrificed by $\mathrm{CO}_{2}$ asphyxiation, perfused with phosphate-buffered saline, and one hemisphere was fixed in $4 \%$ paraformaldehyde for $24 \mathrm{~h}$ for immunohistochemistry. From the remaining 
hemisphere, the cortex and hippocampus were dissected and snap frozen for biochemical analysis.

\section{Novel Object Location Test (NOL)}

The NOL was carried out on a pilot cohort $(n=9)$ at 8 months of age and the full cohort $(n=18)$ at 12 months of age. A cylindrical test arena $(50 \mathrm{~cm}$ diameter $\times 30 \mathrm{~cm}$ height $)$ with spatial cues and three different objects of similar size were used, and mice displayed no object preference during acquisition trials (Fig. 1C, E). On day 1, mice were habituated $(1 \times 10 \mathrm{~min}$ trial $)$ to the test arena. The next day, mice received acquisition trials $(2 \times 5 \mathrm{~min} ; 6 \mathrm{~min}$ inter-trial inter$\mathrm{val})$ and were allowed to freely explore the test arena and the three objects therein. After 24 h, mice were reintroduced to the test arena for a single retention trial ( $5 \mathrm{~min})$ with one object having moved location (Fig. 1B). Exploration was defined as touching the object with its nose or whiskers, or the animals' snout was directed at the object at a distance of $\leq 2 \mathrm{~cm}$. Exploration was assessed live by human observations and confirmed through video analysis by blinded analyzers. The results from the live measurements were used here. The discrimination index was calculated as the time spent exploring the displaced object $\left(\mathrm{O}_{\mathrm{d}}\right)$ over the average time exploring the stationary objects $\left(\mathrm{O}_{\mathrm{s}}\right)$ plus time exploring displaced object multiplied by $100,\left(\mathrm{O}_{\mathrm{d}} /\left(\mathrm{O}_{\mathrm{s}}+\mathrm{O}_{\mathrm{d}}\right)\right)^{*} 100$.

\section{Morris Water Maze (MWM)}

The MWM (145 cm diameter $\times 60 \mathrm{~cm}$ height) was set up with spatial cues surrounding the tank. On day 1 , mice carried out $5 \times 1 \mathrm{~min}$ trials ( $20 \mathrm{~min}$ inter-trial interval) with randomized and changing entry points and a small escape platform $(9 \mathrm{~cm}$ width $\times 9 \mathrm{~cm}$ length) visible $1.5 \mathrm{~cm}$ over the water placed in alternating quadrants. If unsuccessful, mice were guided to the platform and left for $20 \mathrm{~s}$. On acquisition days $2-5$, mice carried out $5 \times 1$ min trials ( 20 min inter-trial interval) with randomized and changing entry points and the platform location fixed and submerged. If unsuccessful, mice were guided to the platform for $20 \mathrm{~s}$. On day 6 , the probe trial consisted of a single $1 \mathrm{~min}$ trial with no platform present (Fig. 2A). Swimming traces are included in Sup. Figure 2. The time spent in the platform area, defined as the exact dimensions of where the platform was located in the acquisition trials, was recorded using EthoVision software as a measure of spatial learning and memory.

\section{Sample Preparation for FACS}

Preparation of FACS tissue was carried out as previously described [62]. Cortex from perfused brains was mechanically homogenized and enzymatically digested before straining and separating through a Percoll gradient. Antibodies for
CD3 (APC hamster anti-mouse CD3; 1:200; BD Bioscience \#553,066), CD11b (PE rat anti-CD11b; 1:200; BD Bioscience \#557,397), and CD45 (FITC rat anti-mouse CD45; 1:100; BD Bioscience \#553,079) were added to cell suspensions and whole blood samples before the samples were washed and centrifuged, and the pellet resuspended in flow cytometry buffer. Samples were sorted on a FACS Aria ${ }^{\mathrm{TM}}$ Fusion cell sorter (Becton Dickenson), lymphocytes were identified as $\mathrm{CD} 3+$, and macrophages were identified as being CD11b + CD45hi.

\section{Immunohistochemistry}

Free-floating $30 \mu \mathrm{m}$ sections were blocked with $10 \%$ BSA, $0.5 \%$ triton-X for $2 \mathrm{~h}$ followed by incubation in rabbit anti-Iba1 (1:1000; Wako) overnight at $4{ }^{\circ} \mathrm{C}$. Sections were incubated in goat-anti-rabbit ALEXA Fluor-488 (1:1000; Invitrogen \#a1 1008) for $2 \mathrm{~h}$ before being counterstained with Hoechst and mounted using SlowFade Gold mounting medium. Z-stack images were taken on a Leica SP8 confocal microscope at $\times 20$ magnification. To measure microglial number Iba1-positive cells were manually counted. Microglial branching was assessed by skeleton analysis as described [78].

\section{Enzyme-Linked Immunosorbent Assay}

IL-6 (DY406) and IL-10 (DY417; R\&D Systems) DuoSet ELISA kits were used for cytokine quantification and were carried out as per the manufacturer's instructions. The plates were incubated in capture antibody overnight at room temperature and then blocked-in reagent diluent. Samples and standards were added, and the plates were incubated overnight at $4{ }^{\circ} \mathrm{C}$. A detection antibody was added for $2 \mathrm{~h}$ at room temperature before streptavidin-HPR incubation for $20 \mathrm{~min}$ and substrate incubation for $20 \mathrm{~min}$. The reaction was terminated with a stop solution and the plate read at $490 \mathrm{~nm}$.

\section{Immunoblot}

Tissue was manually homogenized (10\% w/v) in RIPA buffer containing cOmplete ${ }^{\mathrm{TM}}$ mini protease inhibitors (Sigma \#04,693,159,001). The homogenate was sonicated $(6 \times 5 \mathrm{~s}, 20 \%$ pulse $)$, centrifuged $(12,000 \mathrm{~g} ; 20 \mathrm{~min}$; $4{ }^{\circ} \mathrm{C}$ ) and the supernatant stored at $-80{ }^{\circ} \mathrm{C}$. Western blotting was conducted as previously described (Rutkowska et al. 2017) and where required membranes were stripped with ReBlot plus (Millipore) for 3 min. For tau and p-tau, membranes were cut to allow for the simultaneous detection of actin. The primary antibodies were: mouse antiphospho-tau AT8 (1:500; Thermo Scientific \#MN1020), mouse anti-tau46 (1:1000; Cell Signaling \#4019), mouse 
Fig. 1 Fingolimod improves performance in the NOL at 8 and 12 months of age. A Timeline of reported $3 \times \mathrm{Tg}$ AD mouse pathology and experimental plan for this study. B Experimental design for the NOL test. C, E At 8 and 12 months of age mice demonstrated no preference to any of the three objects during the acquisition phase of the NOL test. D At 8 months of age a genotype-related reduction in discrimination index was observed $\left(p=0.0332, F_{(1,25)}=5.083\right)$.

Post hoc analysis revealed that vehicle-treated $3 \mathrm{xTg}$-AD mice performed significantly worse than WT ( $p=0.0055, n=6-8)$ and that this was attenuated by treatment with fingolimod $(p=0.0054, n=6-8)$. (F) At 12 months of age a genotyperelated reduction in discrimination index was observed $\left(p=0.0204, F_{(1,41)}=5.823\right)$. Post hoc analysis revealed that vehicle-treated $3 \times \mathrm{Tg}-\mathrm{AD}$ mice performed significantly worse than WT ( $p=0.0211, n=9-14)$ and that this was attenuated by treatment with fingolimod $(p=0.0341, n=9-14)$. All data was normally distributed and expressed as mean $\pm \mathrm{SEM}$, $p<0.05, * * p<0.01$

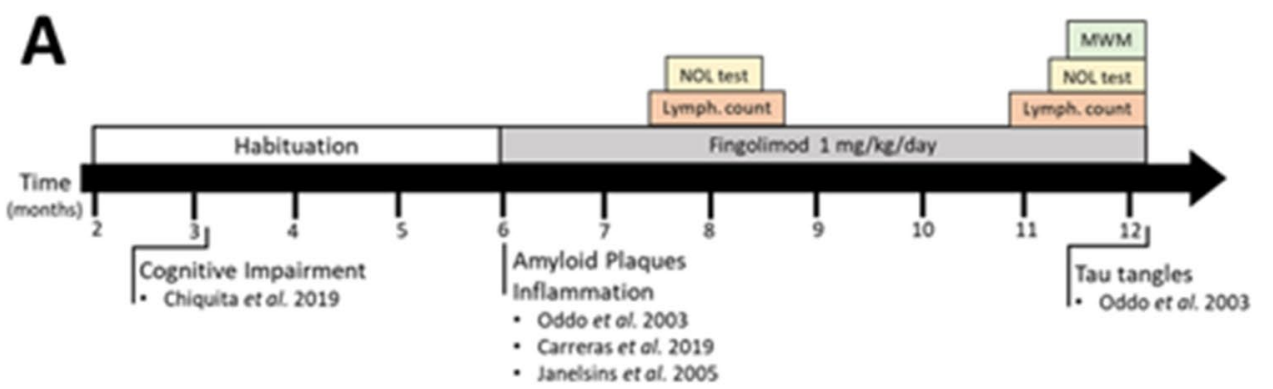

B

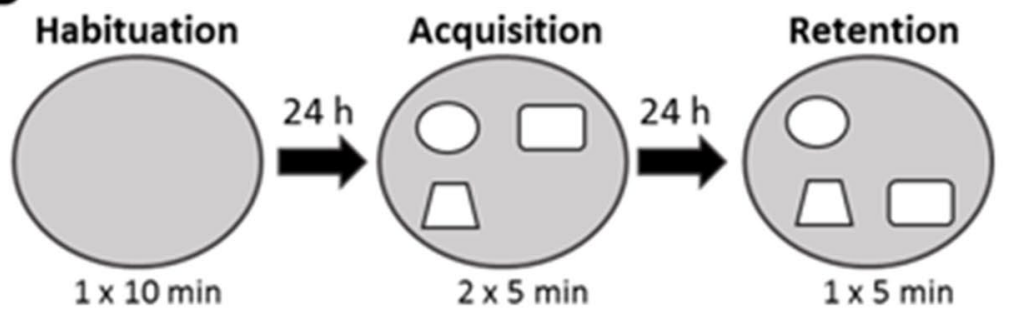

C

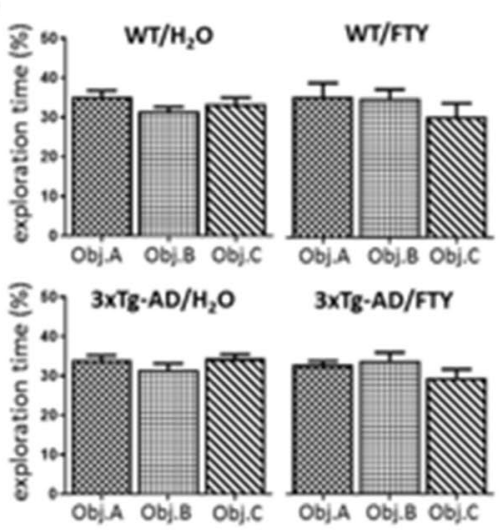

D

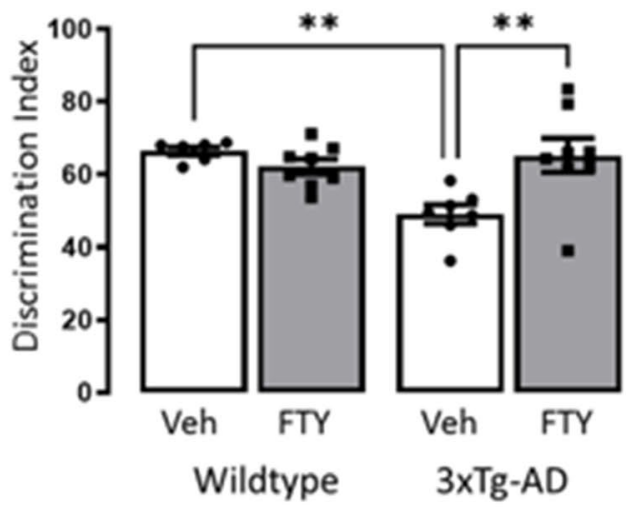

E

$\mathbf{F}$

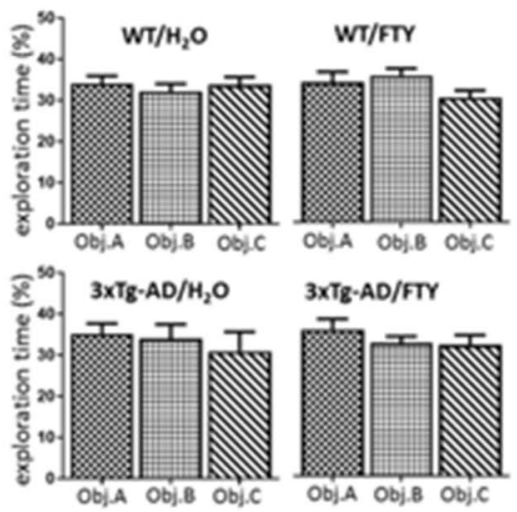

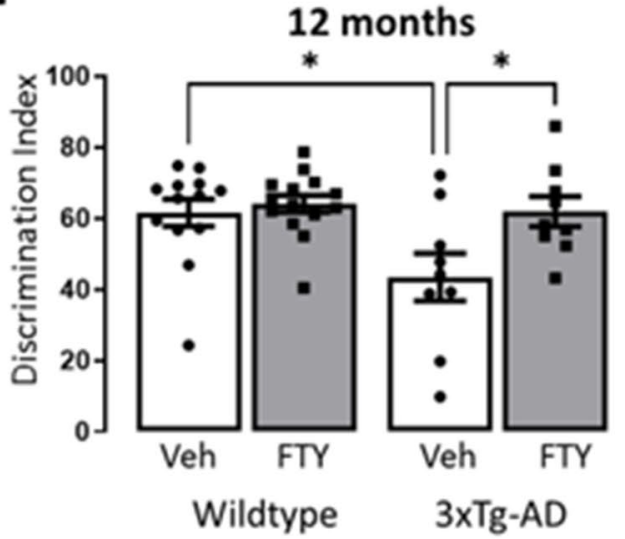

anti- $\beta$-amyloid 6E10 (1:500; Biolegend \#SIG39320), and rabbit anti- $\beta$-actin (1:1000; Sigma \#28,227). The secondary antibodies were: anti-mouse-HRP (1:1000; Sigma \#a8924) and anti-rabbit-HRP (1:2000; GE Health \#na934).

\section{Statistics}

All statistics were carried out on GraphPad Prism 9 software. The data were normally distributed and data points 


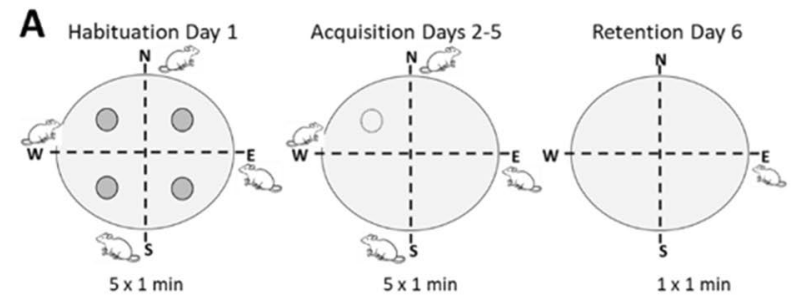

B
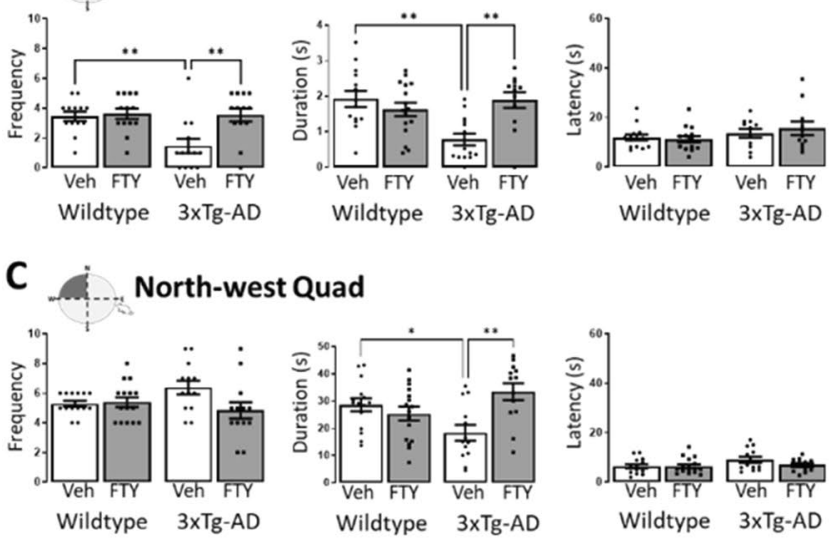

Fig. 2 Fingolimod improves MWM performance in 3xTg-AD mice at 12 months of age. A Experimental design for the MWM test. B A genotype-related reduction in frequency of entries to $(p=0.0195$, $\left.F_{(1,48)}=6.813\right)$, and duration in $\left(p=0.0331, F_{(1,52)}=4.79\right)$ the platform area, with no difference observed in latency. Post hoc analysis revealed that vehicle treated $3 \times \mathrm{Tg}-\mathrm{AD}$ mice entered the platform area less frequently $(p=0.0046, n=13)$ and remained there for less time $(p=0.001, n=14)$ than WT controls. Fingolimod treated $3 \times \mathrm{Tg}-\mathrm{AD}$ mice entered the platform area more frequently $(p=0.0031, n=13)$ and for a longer duration $(p=0.025, n=12-14)$ than vehicle treated $3 \mathrm{xTg}-\mathrm{AD}$ mice. $\mathrm{C}$ In the north-west quadrant, where the platform was

greater than two standard deviations from the mean were excluded from groups. In all cases, 2-way ANOVA was applied to compare the means and where significance was observed Tukey post hoc correction for multiple comparisons was carried out with $p<0.05$ as the minimum level of significance. Graphical data is represented as mean \pm SEM and post hoc significance indicated as follows: ${ }^{*} p<0.05$, $* * p<0.01, * * * p<0.001, * * * * p<0.0001$.

\section{Results}

\section{Fingolimod Improves Memory Deficits in 3xTg-AD Mice}

Cognitive impairment, such as memory loss, is one of the primary symptoms of $\mathrm{AD}$ and is known to develop in 3xTgAD mice from 3 months of age $[8,16]$. We assessed spatial learning and memory in 3xTg-AD mice at 8 and 12 months of age, after 2 and 6 months of fingolimod treatment $(1 \mathrm{mg} /$
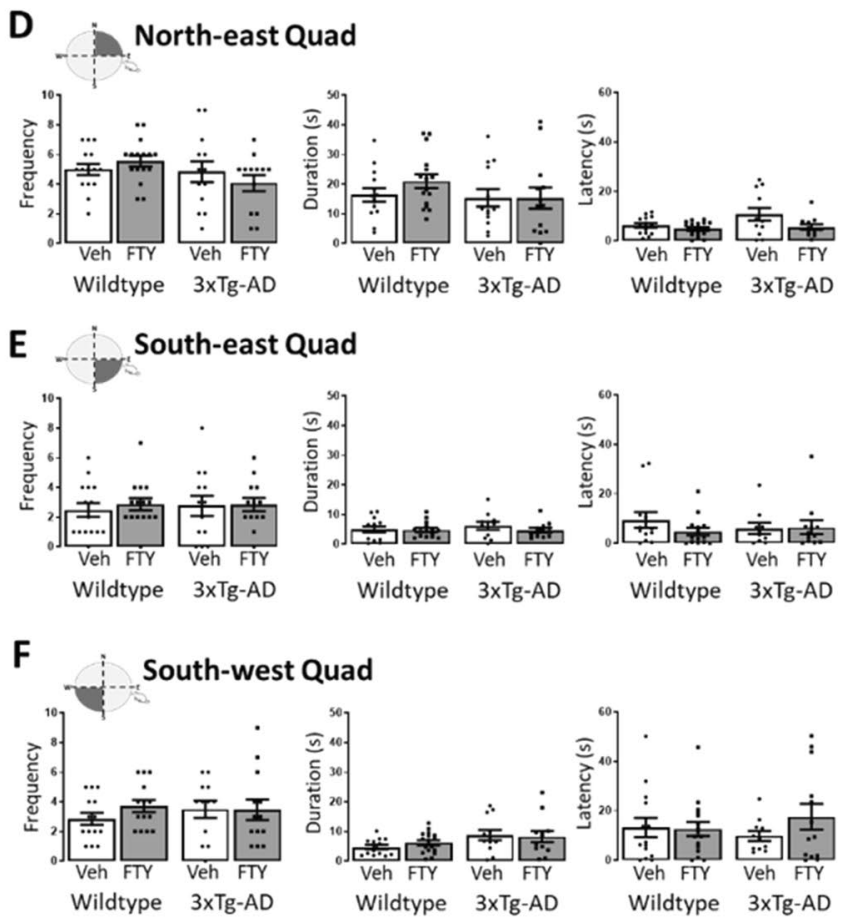

located, a genotype-treatment interaction in duration was observed $\left(p=0.0012, F_{(1,53)}=11.65\right)$ but no difference in frequency of entries or latency was noted. Post hoc analysis revealed that vehicle-treated $3 \mathrm{xTg}-\mathrm{AD}$ mice spent significantly less time in the northwest quadrant compared to WT controls ( $p=0.0471, n=13-15)$ and that this was alleviated by treatment with fingolimod ( $p=0.002, n=13)$. D, E, F No significant difference was observed between groups in frequency of entry, duration in the quadrant, or latency to the quadrant in the north-east, south-east, or south-west quadrants. All data was normally distributed and expressed as the mean \pm SEM, $* p<0.05, * * p<0.01$

$\mathrm{kg} /$ day), respectively (Fig. 1A). At 8 months of age a genotype-related impairment in working memory was observed during the NOL test $\left(p=0.0332, F_{(1,25)}=5.083\right.$; Fig. 1D) and post hoc analysis revealed that treatment with fingolimod significantly improved NOL performance in $3 \times \mathrm{Tg}-\mathrm{AD}$ mice (Veh: 49.12 \pm 2.588 , FTY: $65.32 \pm 4.7 ; p=0.0054, n=6-8$ ). The genotype-related impairment was again observed at 12 months of age $\left(p=0.0204, F_{(1,41)}=5.823\right.$; Fig. $\left.1 \mathrm{~F}\right)$ and post hoc analysis determined that $3 \mathrm{xTg}-\mathrm{AD}$ mice treated with fingolimod performed significantly better than vehicle-treated controls (Veh: $43.45 \pm 6.66$, FTY: $61.9 \pm 4.224$; $p=0.0341, n=9-14)$.

At 12 months of age, MWM was also carried out. No difference in athletic ability was observed as indicated by distance traveled and velocity between the groups (Sup. Figure 1A, B). Escape latency during the training days 2-5 reduced in all groups over time but by training day 5 vehicle-treated 3xTg-AD mice performed significantly worse than their WT counterparts ( $p=0.017, n=14-18$; Sup. Figure $1 \mathrm{C}$ ). On test day 6 , frequency of entry to the platform 
area $\left(p=0.0195, F_{(1.48)}=6.813\right.$; Fig. 2B), duration of time in the platform area $\left(p=0.0331, F_{(1,52)}=4.79\right.$; Fig. $\left.2 \mathrm{~B}\right)$, and duration of time in the north-west (platform containing) quadrant $\left(p=0.0012, F_{(1,53)}=11.65\right.$; Fig. $\left.2 \mathrm{C}\right)$ were all reduced in $3 \times \mathrm{Tg}-\mathrm{AD}$ mice compared with WT controls. Post hoc analysis revealed that $3 \mathrm{xTg}$-AD mice receiving fingolimod entered that platform area more frequently than vehicle treated controls (Veh: $1.46 \pm 0.48$, FTY: $3.54 \pm 0.43$; $p=0.0031, n=13)$ and spent a longer duration of time in the platform area (Veh: $0.78 \pm 0.17$, FTY: $1.89 \pm 0.22$; $p=0.0025, n=12-14)$ and north-west quadrant (Veh: $18.31 \pm 2.89$, FTY: $33.44 \pm 3.07 ; p=0.002, n=13$ ). Taken together these data demonstrate that fingolimod improves working memory in 8- and 12-month-old 3xTg-AD mice after 2 and 6 months of treatment, respectively.

\section{Fingolimod Reduces Microglial Activation in 3xTg-AD Mice}

Inflammation in the CNS compounds the progression of $\mathrm{AD}$ and is an important therapeutic target [41]. We therefore investigated the functional state of microglia in fingolimod-treated $3 \times \mathrm{Tg}$-AD mice by assessing the proliferation (Fig. 3A, C) and morphology (Fig. 4A, B) of microglia in the hippocampus. A genotype-related increase in the number of Iba1-positive cells was observed in the CA1 $\left(p=0.0286, F_{(1,8)}=7.098\right.$; Fig. 3B) and CA3 $\left(p=0.0076, F_{(1,8)}=12.56\right.$; Fig. 3D) and post hoc analysis revealed that treatment with fingolimod significantly reduced the number of Iba1-positive cells in 3xTg-AD mice (Veh CA1: 0.251 \pm 0.006 , FTY CA1: $0.201 \pm 0.009$, $p=0.0174, n=3$; Veh CA3: $0.233 \pm 0.012$, FTY CA3: $0.169 \pm 0.013 ; p=0.0151, n=3)$. Skeleton analysis was carried out to further examine the morphology of microglia. A genotype-related reduction in branch number was observed in the CA1 $\left(p=0.0061, F_{(1,8)}=13.65\right.$; Fig. 4 C) while branch number $\left(p<0.0006, F_{(1,8)}=29.49\right.$; Fig. 4 C) and length $\left(p=0.0001, F_{(1,8)}=45.61 ;\right.$ Fig. 4D) was reduced in the CA3. Post hoc analysis determined that treatment with fingolimod increased microglial branch number in the CA1 (Veh: $14.13 \pm 2.13$, FTY: $25.15 \pm 1.07 ; p=0.0111$, $n=3$ ) and CA3 (Veh: $14.57 \pm 0.63$, FTY: $28.64 \pm 1.88$;
Fig. 3 Fingolimod reduces microglial number in $3 \times \mathrm{Tg}-\mathrm{AD}$ hippocampus. Iba1 stained sections were used to assess microglial proliferation in the (A) CA1 and (C) CA3 regions of the hippocampus. A significant genotype-related increase in Iba1-positive cells was observed in the CA1 (B: $p=0.0286$, $\left.F_{(1,8)}=7.098\right)$ and CA3 (D: $\left.p<0.0076, F_{(1,8)}=12.56\right)$ of $3 x T g-A D$ mice. Post hoc analysis revealed that $3 \mathrm{xTg}-\mathrm{AD}$ mice had significantly more Iba1-positive cells than WT (B: CA1, $p=0.0446, n=3$; D: CA3, $p=0.0025, n=3$ ) and that this was alleviated in fingolimod treated $3 \times \mathrm{Tg}-\mathrm{AD}$ mice $(\mathbf{B}$ : CA1, $p=0.0174, n=3$; D: CA3, $p=0.0151, n=3$ ). Data are expressed as the mean \pm SEM, $* p<0.05, * * p<0.01$. Scale bar $100 \mu \mathrm{m}$

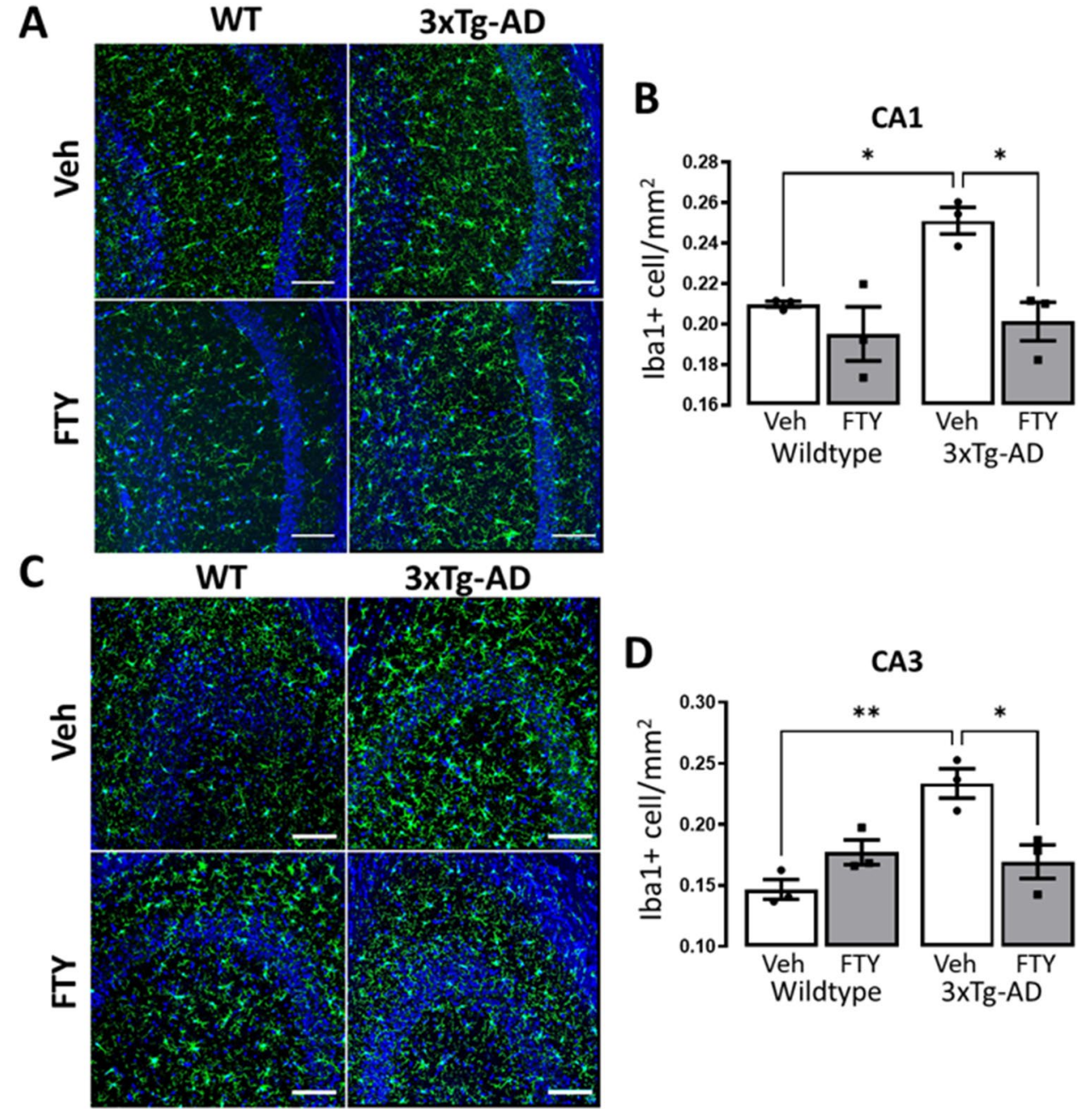


A

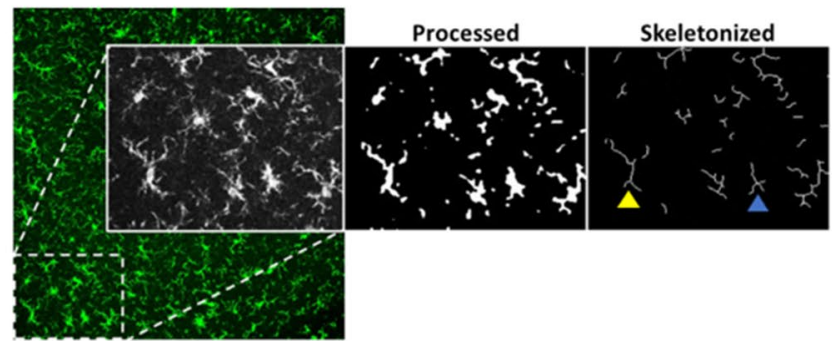

C
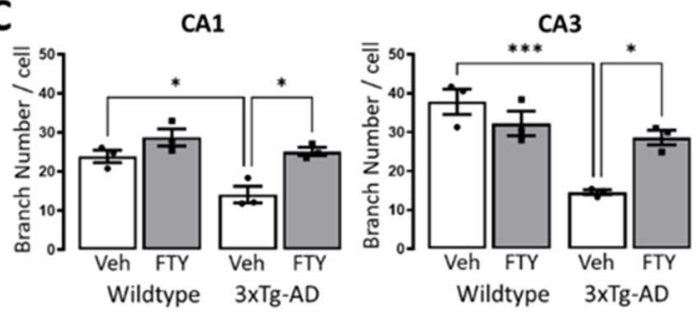

Fig. 4 Fingolimod reduces microglia reactivity in 3xTg-AD mice. Iba1-positive cells were assessed by skeleton analysis to determine (A) activated or (B) ramified morphology through branch number (low branch number yellow arrow, high branch number purple arrow) and branch length (short branch length blue arrow, long branch length red arrow). C A genotype-related reduction in branch number was observed in the CA1 $\left(p<0.0061, F_{(1,8)}=13.65\right)$ and CA3 $\left(p=0.0006, F_{(1,8)}=29.49\right)$. Post hoc analysis revealed that microglia in vehicle treated $3 \times \mathrm{Tg}-\mathrm{AD}$ mice had significantly fewer branches than in WT (CA1: $p=0.0215, n=3$; CA3: $p=0.007, n=3$ ) and

$p=0.0163, n=3$ ) as well as increasing microglial branch length in the CA3 (Veh: $34.6 \pm 2.75$, FTY: $58.37 \pm 2.69$; $p=0.0005)$ of $3 \times \mathrm{Tg}-\mathrm{AD}$ mice. Taken together these data reveal that $3 \times \mathrm{Tg}-\mathrm{AD}$ mice display increased microglial proliferation and the development of a reactive microglial morphology and that treatment with fingolimod reduces this microglial reactivity.

\section{Fingolimod Reduces Circulating and Infiltrating Lymphocytes}

The canonical activity of fingolimod is well described and involves the retention of lymphocytes in lymph nodes [10]. As expected, a treatment-related reduction in circulating lymphocytes was detected in mice treated with fingolimod after 2 $\left(p<0.0001, F_{(1,22)}=36.49\right)$ and $6\left(p=0.0013, F_{(1,38)}=12.07\right)$ months of treatment (Fig. 5A). FACS analysis was carried out on blood and cortical tissue from experimental animals at 12 months of age (Fig. 5B). Cell sorting confirmed the treatment-related reduction in circulating $\mathrm{CD} 3+\mathrm{T}$ cells $\left(p=0.049, F_{(1,22)}=4.335\right.$; Fig. 5C) and also demonstrated that fingolimod reduced the number of infiltrating CD3 $+\mathrm{T}$ cells in the cortex $\left(p=0.026, F_{(1,18)}=5.925\right.$; Fig. $\left.5 \mathrm{C}\right)$.
B

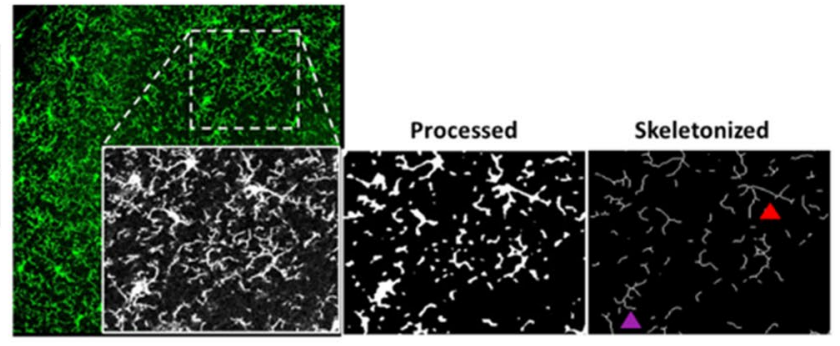

D

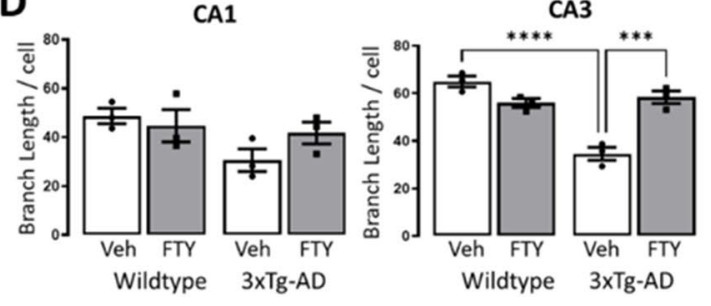

that this was reversed with fingolimod treatment (CA1: $p=0.0111$, $n=3$; CA3: $p=0.0163, n=3)$. D A genotype-treatment interaction in microglial branch length was observed in the CA3 $(p=0.0001$, $\left.F_{(1,8)}=45.61\right)$ but not CA1. Post hoc analysis revealed that branch length in vehicle treated $3 \times \mathrm{XTg}-\mathrm{AD}$ mice was smaller than that in WT controls $(p<0.0001, n=3)$ and that increased branch length was observed in fingolimod treated $3 \times \mathrm{Tg}-\mathrm{AD}$ mice $(p=0.0005, n=3)$. Data are expressed as the mean $\pm \mathrm{SEM}, * p<0.05$, *** $p<0.001$, $* * * * p<0.0001$

\section{Fingolimod Improves the Cytokine Profile in 3xTg-AD Mice}

We next quantified the levels of the pro- and anti-inflammatory cytokines, IL-6 and IL-10, in tissue homogenates of the hippocampus and cortex using ELISA. No difference in levels of hippocampal IL-6 was observed between groups; however, a genotype/treatment interaction was observed in cortical IL-6 ( $p=0.0225$, $F_{(1,19)}=6.169$; Fig. 6A). Post hoc analysis determined that cortical IL-6 was significantly reduced in $3 \times \mathrm{Tg}-\mathrm{AD}$ mice receiving fingolimod compared to vehicle controls (Veh: $2.424 \pm 0.13$, FTY: $1.881 \pm 0.15 ; p=0.0182$, $n=5-6)$. A treatment-related increase in hippocampal IL-10 was observed ( $p=0.0121, F_{(1,15)}=8.138$; Fig. 6B). In cortical tissue, a genotype/treatment interaction was observed ( $p=0.0298, F_{(1,22)}=5.398$; Fig. 6B) and post hoc analysis revealed that IL-10 was significantly increased in 3xTg-AD mice receiving fingolimod compared to vehicle-treated controls (Veh: $60.57 \pm 4.04$, FTY: $81.58 \pm 8.15 ; p=0.0277, n=6-7)$. These data support a shift in the cytokine profile of $3 \times \mathrm{Tg}$-AD mice after fingolimod treatment from pro-inflammatory to anti-inflammatory. 
Fig. 5 Fingolimod reduces circulating and CNS-infiltrating lymphocytes. A Blood was drawn from the sub-mandibular vein and lymphocytes measured on the Sysmex KX-21. A significant genotyperelated increase in circulating lymphocytes was observed at 8- $\left(p=0.0079, F_{(1,22)}=8.524\right.$, $n=5-10)$ and 12 months $\left(p=0.0077, F_{(1,38)}=7.917\right.$, $n=7-12)$ of age. Concomitantly a treatment-related reduction was also observed at $8\left(p<0.0001, \mathrm{~F}_{(1,22)}=36.49\right.$, $n=5-10)$ and 12 months $\left(p=0.0013, F_{(1,38)}=12.07\right.$, $n=7-12)$ of age. B Representative gating strategy for sorting $\mathrm{CD} 3+\mathrm{T}$ cells. $\mathrm{C}$ FACS analysis confirmed the treatmentrelated reduction in circulating CD $3+\mathrm{T}$ cells $(p=0.049$, $\left.F_{(1,22)}=4.335, n=6-9\right)$ and $\mathrm{CD} 3+\mathrm{T}$ cells in the cortex $\left(p=0.026, F_{(1,18)}=5.925\right.$, $n=4-6)$. Data are expressed as the mean \pm SEM
A

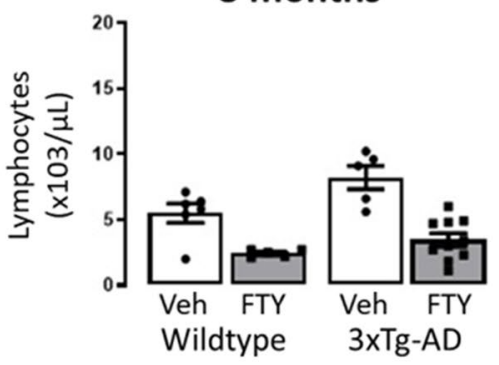

8 months

12 months

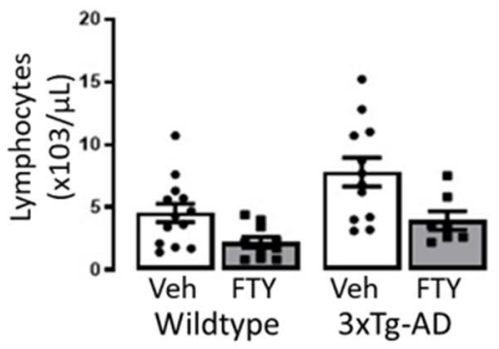

B

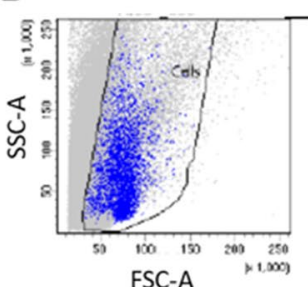

FSC-A

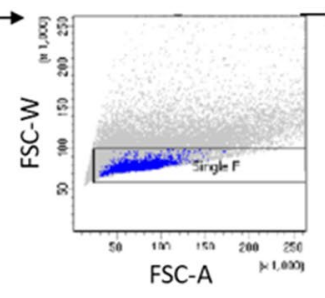

Blood

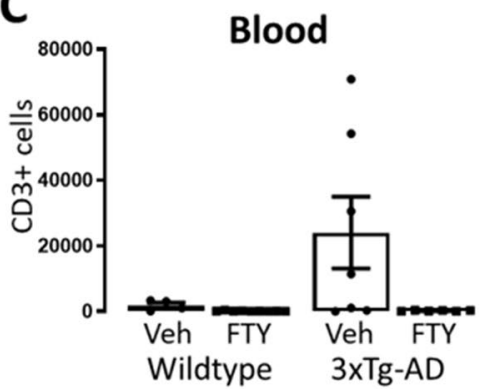

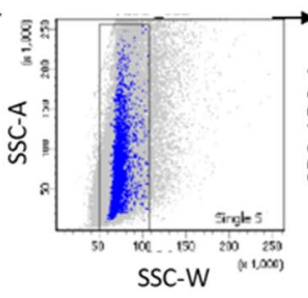

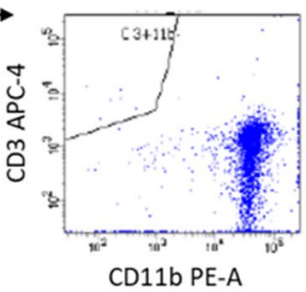

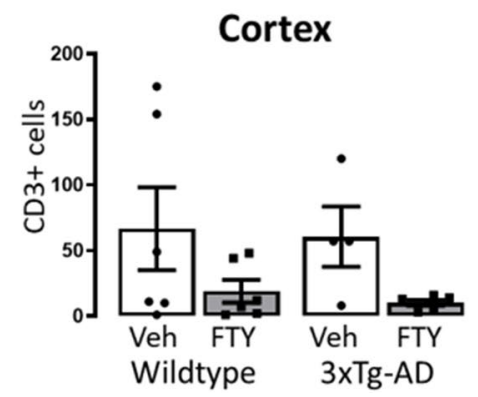

Fingolimod Reduces Tau Phosphorylation and APP Expression in 3xTg-AD Mice

Neurofibrillary tangles of hyperphosphorylated tau and amyloid plaques are hallmarks of $\mathrm{AD}$ and develop in $3 \times \mathrm{Tg}$ AD [16, 59]. Phospho-tau burden and APP load were assessed through immunoblot (Fig. 7C). As expected a significant genotype-related increase in total tau protein was observed in the cortex and hippocampus of $3 \times \mathrm{Tg}-\mathrm{AD}$ mice by Tau46 antibody (cortex: $p=0.0076, F_{(1,16)}=9.306$; hippocampus: $p=0.0265, F_{(1,16)}=5.975$; Fig. 7A). A concomitant genotype-related increase in tau phosphorylated at Ser202/Thr205 was observed using AT8 antibody (cortex: $p=0.0242, F_{(1,12)}=6.649$; hippocampus: $p=0.0018$, $F_{(1,23)}=12.5$; Fig. 7B). Post hoc analysis revealed that treatment with fingolimod significantly reduced the level of phosphorylated tau in the cortex (Veh: 138.2 \pm 16.23 , FTY: $53.15 \pm 15.82 ; p=0.0198, n=4$ ) and hippocampus (Veh: $215.9 \pm 53.16$, FTY: $55.44 \pm 12.27 ; p=0.0012, n=6-7)$ of $3 \times \mathrm{Tg}-\mathrm{AD}$ mice. The deposition of $\mathrm{A} \beta$ plaques is another key feature in the development of $\mathrm{AD}$, and while extensive plaque burden is present in female $3 \times \mathrm{Tg}$-AD mice previous reports have demonstrated limited plaque burden in $3 \times \mathrm{Tg}$ AD males of this age [13]. Consistent with this, we observed a limited plaque burden in our mice (Supp. Figure 2). We then measure the level of the A $\beta$ parent protein, APP. A genotype-related increase in APP was observed in the cortex of 3xTg-AD mice using 6E10 antibody $(p<0.0001$, $F_{(1,8)}=147.6$; Fig. 7D). Post hoc analysis determined that treatment with fingolimod reduced the level of APP in the cortex of $3 \times \mathrm{Tg}-\mathrm{AD}$ mice (Veh: $105.7 \pm 12.29$, FTY: $59.38 \pm 4.99 ; p=0.0051, n=3)$. These data confirm the pathological phosphorylation of tau at Ser202/Thr205 in $3 \times T g-A D$ mice and reveal that fingolimod treatment reduces both APP expression and tau phosphorylation.

\section{Discussion}

In this study, we investigated the effect of fingolimod, an $\mathrm{S} 1 \mathrm{P}$ receptor antagonist, on $\mathrm{AD}$ phenotypes in the $3 \times \mathrm{Tg}$ AD model. Animals were aged for 6 months to allow for the development of pathology and fingolimod was then administered for a further 6 months via the drinking water. The data demonstrate that, in aged $3 \times \mathrm{Tg}-\mathrm{AD}$ mice, treatment with fingolimod reverses disease-associated working memory impairment, alleviates inflammation in the CNS, and reduces the levels of phosphorylated tau and APP. 
Fig. 6 Fingolimod alters the cytokine profile in the $3 \times \mathrm{Tg}-\mathrm{AD}$ brain. IL-6 and IL- 10 concentrations in the cortex and hippocampus were assessed by ELISA. A A genotype-treatment interaction in IL-6 was observed in the cortex $(p=0.0225$, $F_{1,19}=6.169$ ) but not hippocampus. Post hoc analysis revealed a significant reduction in fingolimod-treated $3 \times \mathrm{Tg}$ $\mathrm{AD}$ mice compared to vehicle treated ( $p=0.0182, n=5-6)$. B A significant genotype-treatment interaction was observed in IL-10 levels in the cortex $\left(p=0.0298, F_{(1,22)}=5.398\right)$ and a treatment-related increase in IL-10 was observed in the hippocampus ( $p=0.0121$, $\left.F_{(1,15)}=8.138\right)$. Post-hoc analysis revealed that $3 \mathrm{xTg}-\mathrm{AD}$ mice treated with fingolimod had significantly higher levels of IL-10 in the cortex compared with vehicle controls $(p=0.0277$, $n=6-7)$. Data are expressed as the mean \pm SEM, $* p<0.05$
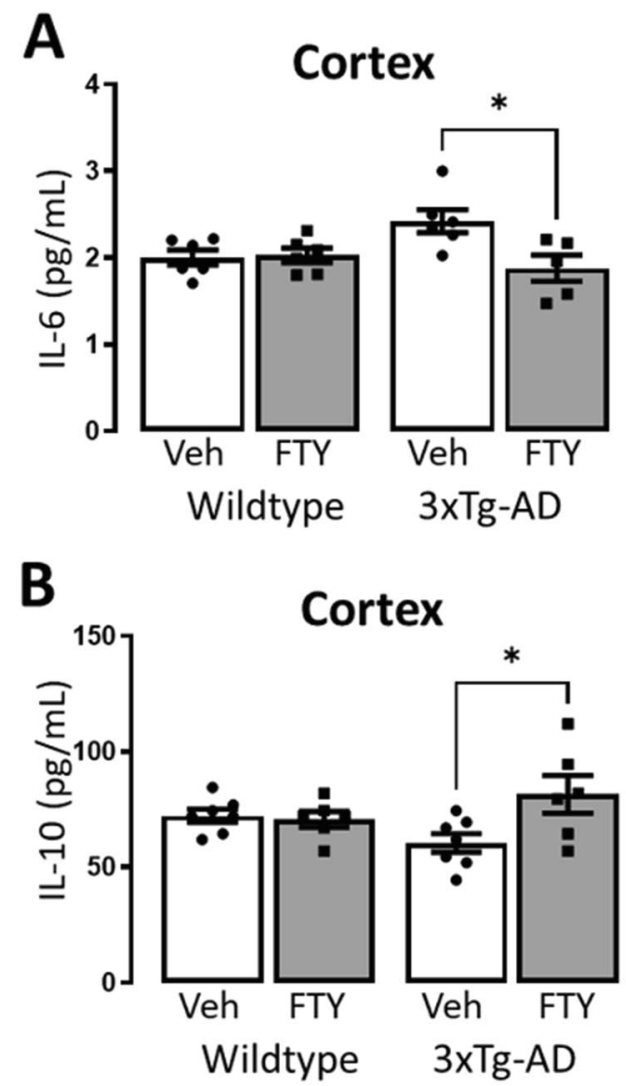
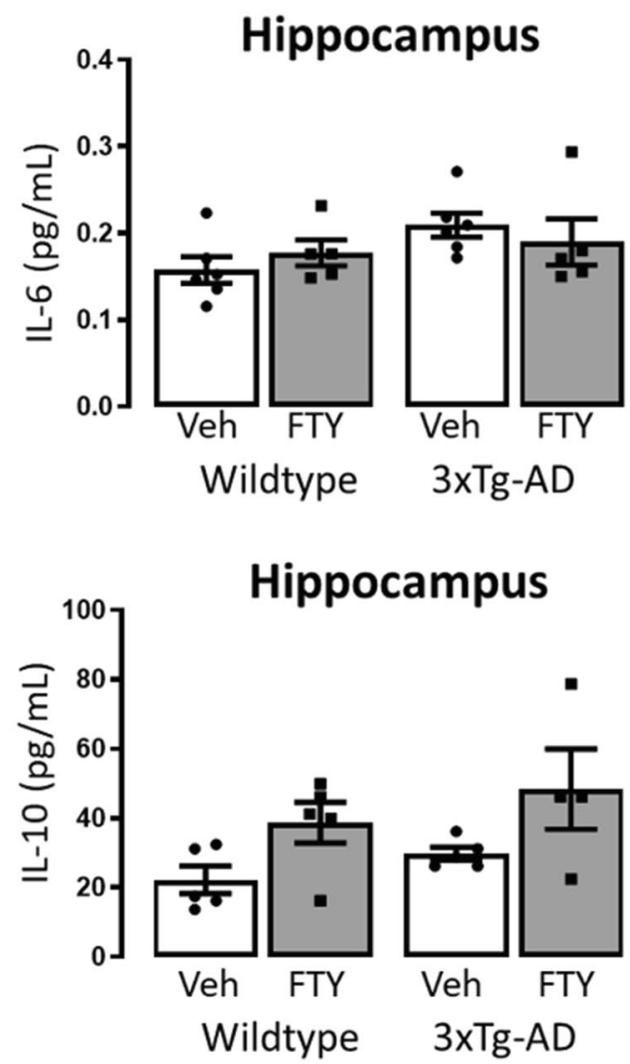

$\mathrm{AD}$ is characterized by the progressive decline in cognition, where memory impairment and behavioral disturbances affect daily activities $[23,26]$. In $3 x T g-A D$ mice impaired spatial working memory and increased anxiety have been reported from 3 and 6 months of age, respectively $[16,18,67,80]$. Previous studies have highlighted the potential benefits of fingolimod administration on memory impairment, however, in those studies treatment began prior to the decline in cognition and must be considered a preventative measure $[6,12,32]$. Our data demonstrate that administration of fingolimod after the reported onset of memory decline in $3 \mathrm{xTg}-\mathrm{AD}$ mice results in a restoration of spatial working memory extending to 12 months of age.

Inflammation in the CNS is an important factor in the onset and progression of $\mathrm{AD}$. Recent studies using positron emission tomography have revealed chronic microglial activation in the $\mathrm{AD}$ brain and have used this as a predictor of cognitive decline [46-48, 61]. Postmortem analyses have also confirmed the significant increase in microglial activation observed in the $\mathrm{AD}$ brain [36, 70]. In 3xTg-AD mice increased microglial number and elevated proinflammatory cytokines have been reported from 6 months of age [12, $14,32,37]$. In line with this, we report increased microglial number in the hippocampus of 12-month 3xTg-AD mice compared to WT controls and have demonstrated that these cells develop an activated morphology as measured by reduced branch length and number. Consistent with previous studies we have shown that treatment with fingolimod reduces the number of microglial cells and, furthermore, have demonstrated that microglia in treated mice display a resting morphology.

Mounting evidence has highlighted the infiltration of peripheral lymphocytes to the brain parenchyma of $\mathrm{AD}$ patients $[24,51,75]$. This has also been reported in APP and tau transgenic mice and has been shown to further compound inflammation in the CNS [11, 25, 43]. Here, we report for the first time the detection of CD3 + T-cell lymphocytes in the cortex of 3xTg-AD mice. Furthermore, treatment with fingolimod reduced the level of circulating lymphocytes and we note a concomitant reduction in CD3 + T-cell lymphocytes in the brains of $3 \times \mathrm{Tg}-\mathrm{AD}$ mice.

Previous A $\beta$-infusion models of AD have shown that fingolimod reduces proinflammatory TNF- $\alpha$ and COX-II levels while increasing brain-derived neurotrophic factor (BDNF) [6],Fukumoto et al. 2014a; [32]. Similarly, our data have identified a fingolimod-mediated switch from a pro-inflammatory to anti-inflammatory cytokine profile in the cortex and hippocampus of 3xTg-AD mice with a reduction in IL-6 and an increase in IL-10 concentrations. Interestingly, the effect of fingolimod on IL-6 and IL-10 is observed in 3xTgAD mice only and not WT. No genotype-related alteration in 
Fig. 7 Fingolimod reduces pathological hallmarks in 3xTg$\mathrm{AD}$ mice. $\mathbf{C}$ The protein levels of Tau (Tau46), phospho-Tau (AT8), and APP (4G8) were measured in the cortical and hippocampal tissue of experimental mice. A A genotyperelated increase in tau protein was observed in the cortex $\left(p=0.0076, F_{(1,16)}=9.306\right)$ and hippocampus $(p=0.0265$, $\left.F_{(1,16)}=5.975\right)$. B A concomitant genotype-related increase in phospho-tau protein was also observed in the cortex $\left(p=0.0242, F_{(1,12)}=6.649\right)$ and hippocampus $(p=0.0018$, $\left.F_{(1,23)}=12.5\right)$. Post hoc analyses revealed that phospho-tau protein was increased in $3 \times \mathrm{Tg}-\mathrm{AD}$ mice compared to WT (cortex: $p=0.02, n=4$; hippocampus: $p=0.0011, n=6-7)$ and that treatment with fingolimod alleviated this (cortex: $p=0.0198$, $n=4$; hippocampus: $p=0.0012$, $\mathrm{n}=6-7)$. D A significant genotype-related increase was observed in the level of cortical APP $\left(p<0.0001, F_{(1,8)}=147.6\right)$. Post hoc analysis revealed that APP was increased in $3 \times \mathrm{Tg}$ AD mice compared to WT $(p<0.0001, n=3)$ and that this was reduced by treatment with fingolimod ( $p=0.0051$, $n=3)$. Data are expressed as the mean \pm SEM, $* p<0.05$, $* * p<0.01, * * * * p<0.0001$
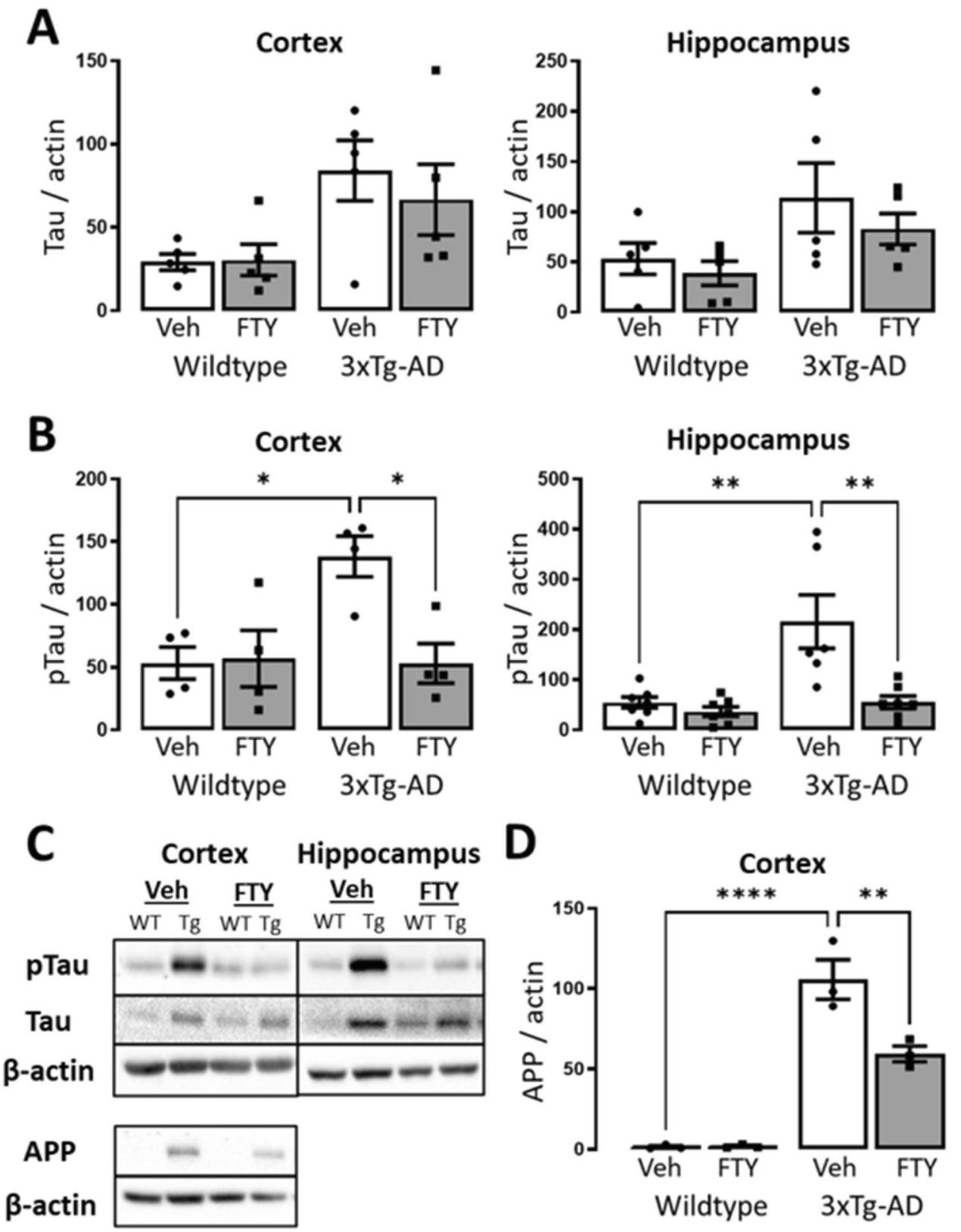

these cytokines was recorded. Further research is required to elucidate this genotype-specific effect of fingolimod.

The characteristic hallmarks of AD are the deposition of extracellular amyloid plaques and the formation of intraneuronal neurofibrillary tangles of hyperphosphorylated tau [21]. These pathologies have been implicated in the death of the neuronal population and chronic activation of the immune response $[17,34,42,45]$. In $3 \times \mathrm{Tg}$ AD mice both amyloid and tau pathology develop by 6 and 12 months of age, respectively [59]. Previous in vitro and in vivo studies have demonstrated that fingolimod reduces $\mathrm{A} \beta$ production in neurons and the formation of amyloid plaques [7, 72], and reduces APP expression in Schwann cells [2]. The use of male mice only in this study limited our examination of $\mathrm{A} \beta 40 / 42$ levels and plaque burden [13], and we note that future studies should include the examination of female mice in the cohort. However, consistent with previous findings, our data indicates that fingolimod reduces the expression of APP in the cortex of $3 \times \mathrm{Tg}-\mathrm{AD}$ mice which may explain the reduction in $\mathrm{A} \beta$ previously reported. Furthermore, alteration of the S1P system in the form of reduced S1P-lyase has been shown to affect APP degradation [40]. While out of the scope of this current study the effect of the S1P system on APP production and degradation merits further study. Finally, we demonstrate for the first time that fingolimod reduces the level of phosphorylated tau in the cortex and hippocampus of 3xTg-AD mice with no effect on total tau. One possible 
mechanism is through the reduction in glycogen synthase $3 \beta$, one of the primary kinases for tau. While it has not yet been demonstrated in neurons, fingolimod has been shown to reduce the level of glycogen synthase $3 \beta$ in a number of cell types $[44,64,74]$.

$\mathrm{AD}$ is a multifactorial disease involving the complex interaction between amyloid plaque formation, phosphorylated tau misfolding, and chronic inflammation in the CNS resulting in widespread neuronal loss and fatal cognitive decline. Therapeutic intervention is currently limited and clinical trials targeting these hallmarks individually have yielded little success. This study has demonstrated that treatment with fingolimod reduces inflammation in the CNS, reduces APP and tau phosphorylation, and restores spatial working memory in male $3 \mathrm{xTg}$-AD mice. The results here add to the increasing body of evidence indicating that fingolimod should be considered a viable therapeutic agent for the treatment of $\mathrm{AD}$.

Supplementary Information The online version contains supplementary material available at https://doi.org/10.1007/s12035-021-02613-5.

Acknowledgements Funding for this project was supplied by the Health Research Board of Ireland.

Author Contribution SGF and KKD designed the research. SF and SB performed the experiments. SF analyzed the data. SF and KKD wrote the paper.

Funding Open Access funding provided by the IReL Consortium. Funding for this project was provided by the Health Research Board of Ireland.

Data Availability The datasets generated during and/or analyzed during the current study are available from the corresponding author on reasonable request.

Code Availability Not applicable.

\section{Declarations}

Ethics Approval Approval for this study was given by the Health Products Regulatory Authority in Ireland. Project Authorisation Number: AE19136/P037.

Consent to Participate Not applicable.

Consent for Publication All authors have reviewed and approve the contents of the manuscript and consent for publication.

Conflict of Interest The authors declare no competing interests.

Open Access This article is licensed under a Creative Commons Attribution 4.0 International License, which permits use, sharing, adaptation, distribution and reproduction in any medium or format, as long as you give appropriate credit to the original author(s) and the source, provide a link to the Creative Commons licence, and indicate if changes were made. The images or other third party material in this article are included in the article's Creative Commons licence, unless indicated otherwise in a credit line to the material. If material is not included in the article's Creative Commons licence and your intended use is not permitted by statutory regulation or exceeds the permitted use, you will need to obtain permission directly from the copyright holder. To view a copy of this licence, visit http://creativecommons.org/licenses/by/4.0/.

\section{References}

1. Alonso ADC, Mederlyova A, Novak M, Grundke-Iqbal I, Iqbal K (2004) Promotion of hyperphosphorylation by frontotemporal dementia tau mutations. J Biol Chem 279:34873-34881. https:// doi.org/10.1074/jbc.M405131200

2. Ambrosius B, Pitarokoili K, Schrewe L, Pedreiturria X, Motte J, Gold R (2017) Fingolimod attenuates experimental autoimmune neuritis and contributes to Schwann cell-mediated axonal protection. J Neuroinflammation 14:92. https://doi.org/10.1186/ s12974-017-0864-z

3. LMH Antel JP 2016 Sphingosine-1-phosphate receptors in the central nervous and immune systems Curr Drug Targets https:// doi.org/10.2174/1389450116666151001112710

4. LG Apostolova 2016 Alzheimer disease Contin Lifelong Learn Neurol 22419434 https://doi.org/10.1212/CON.0000000000 000307

5. Arranz L, De Castro NM, Baeza I, Giménez-Llort L, De la Fuente M (2011) Effect of environmental enrichment on the immunoendocrine aging of male and female triple-transgenic 3xTg-AD mice for Alzheimer's disease. J Alzheimers Dis 25:727-737. https://doi. org/10.3233/JAD-2011-110236

6. Asle-Rousta M, Kolahdooz Z, Oryan S, Ahmadiani A, Dargahi L (2013) FTY720 (Fingolimod) attenuates beta-amyloid peptide (A 342 )-induced impairment of spatial learning and memory in rats. J Mol Neurosci 50:524-532. https://doi.org/10.1007/ s12031-013-9979-6

7. Aytan N, Choi J-K, Carreras I, Brinkmann V, Kowall NW, Jenkins BG, Dedeoglu A (2016) Fingolimod modulates multiple neuroinflammatory markers in a mouse model of Alzheimer's disease. Sci Rep 6:24939

8. Billings LM, Oddo S, Green KN, McGaugh JL, LaFerla FM (2005) Intraneuronal $A \beta$ causes the onset of early Alzheimer's disease-related cognitive deficits in transgenic mice. Neuron 45:675-688. https://doi.org/10.1016/J.NEURON.2005.01.040

9. Brinkmann V, Cyster JG, Hla T (2004) FTY720: Sphingosine 1-phosphate receptor-1 in the control of lymphocyte egress and endothelial barrier function. Am J Transplant 4:1019-1025. https://doi.org/10.1111/j.1600-6143.2004.00476.x

10. Brinkmann V, Davis MD, Heise CE, Albert R, Cottens S, Hof R, Bruns C, Prieschl E, Baumruker T, Hiestand P, Foster CA, Zollinger M, Lynch KR (2002) The immune modulator FTY720 targets sphingosine 1-phosphate receptors. J Biol Chem 277:21453-21457. https://doi.org/10.1074/jbc.C200176200

11. Browne TC, McQuillan K, McManus RM, O’Reilly J-A, Mills KHG, Lynch MA (2013) IFN- $\gamma$ production by amyloid $\beta$-specific Th1 cells promotes microglial activation and increases plaque burden in a mouse model of Alzheimer's disease. J Immunol 190:2241-2251. https://doi.org/10.4049/jimmunol.1200947

12. Carreras I, Aytan N, Choi JK, Tognoni CM, Kowall NW, Jenkins BG, Dedeoglu A (2019) Dual dose-dependent effects of fingolimod in a mouse model of Alzheimer's disease. Sci Rep 9:1-11. https://doi.org/10.1038/s41598-019-47287-1

13. Carroll JC, Rosario ER, Kreimer S, Villamagna A, Gentzschein E, Stanczyk FZ, Pike CJ (2010) Sex differences in $\beta$-amyloid accumulation in 3xTg-AD mice: role of neonatal sex steroid hormone 
exposure. Brain Res 1366:233-245. https://doi.org/10.1016/j.brain res.2010.10.009

14. Caruso D, Barron AM, Brown MA, Abbiati F, Carrero P, Pike CJ, Garcia-Segura LM, Melcangi RC (2013) Age-related changes in neuroactive steroid levels in 3xTg-AD mice. Neurobiol Aging 34:1080-1089. https://doi.org/10.1016/j.neurobiolaging.2012.10. 007

15. Ceccom J, Loukh N, Lauwers-Cances V, Touriol C, Nicaise Y, Gentil C, Uro-Coste E, Pitson S, Maurage CA, Duyckaerts C, Cuvillier O, Delisle M-B (2014) Reduced sphingosine kinase-1 and enhanced sphingosine 1-phosphate lyase expression demonstrate deregulated sphingosine 1-phosphate signaling in Alzheimer's disease. Acta Neuropathol Commun 2:12. https://doi.org/ 10.1186/2051-5960-2-12

16. Chiquita S, Ribeiro M, Castelhano J, Oliveira F, Sereno J, Batista M, Abrunhosa A, Rodrigues-Neves AC, Carecho R, Baptista F, Gomes C, Moreira PI, Ambrósio AF, Castelo-Branco M (2019) A longitudinal multimodal in vivo molecular imaging study of the 3xTg-AD mouse model shows progressive early hippocampal and taurine loss. Hum Mol Genet 28:2174-2188. https://doi.org/10. 1093/hmg/ddz045

17. Chun W, Johnson G (2007) The role of tau phosphorylation and cleaveage in neuronal cell death. Front Biosci 1:733-756. https:// doi.org/10.2741/2097 (PMID: 17127334)

18. Clark JK, Furgerson M, Crystal JD, Fechheimer M, Furukawa R, Wagner JJ (2015) Alterations in synaptic plasticity coincide with deficits in spatial working memory in presymptomatic $3 \times \mathrm{Tg}-\mathrm{AD}$ mice. Neurobiol Learn Mem 125:152-162. https://doi.org/10. 1016/j.nlm.2015.09.003

19. Clinton LK, Billings LM, Green KN, Caccamo A, Ngo J, Oddo S, McGaugh JL, LaFerla FM (2007) Age-dependent sexual dimorphism in cognition and stress response in the $3 \times \mathrm{Tg}-\mathrm{AD}$ mice. Neurobiol Dis 28:76-82. https://doi.org/10.1016/j.nbd.2007.06.013

20. Couttas TA, Kain N, Daniels B, Lim XY, Shepherd C, Kril J, Pickford R, Li H, Garner B, Don AS (2014) Loss of the neuroprotective factor Sphingosine 1-phosphate early in Alzheimer's disease pathogenesis. Acta Neuropathol Commun 2:9. https://doi. org/10.1186/2051-5960-2-9

21. DeTure MA, Dickson DW (2019) The neuropathological diagnosis of Alzheimer's disease. Mol Neurodegener 14:1-18. https:// doi.org/10.1186/s13024-019-0333-5

22. Dev KK, Mullershausen F, Mattes H, Kuhn RR, Bilbe G, Hoyer D, Mir A (2008) Brain sphingosine-1-phosphate receptors: implication for FTY720 in the treatment of multiple sclerosis. Pharmacol Ther 117:77-93. https://doi.org/10.1016/J.PHARMTHERA.2007. 08.005

23. Dubois B, Feldman HH, Jacova C, DeKosky ST, Barberger-Gateau P, Cummings J, Delacourte A, Galasko D, Gauthier S, Jicha G, Meguro K, O’Brien J, Pasquier F, Robert P, Rossor M, Salloway S, Stern Y, Visser PJ, Scheltens P (2007) Research criteria for the diagnosis of Alzheimer's disease: revising the NINCDS-ADRDA criteria. Lancet Neurol 6:734-746. https://doi.org/10.1016/S14744422(07)70178-3

24. Esteras N, Alquézar C, de la Encarnación A, Martín-Requero A (2016) Lymphocytes in Alzheimer's disease pathology: altered signaling pathways. Alzheimer Res 13:439-449. https://doi.org/ 10.2174/1567205013666151116124912 (PMID: 26567747)

25. Ferretti MT, Merlini M, Späni C, Gericke C, Schweizer N, Enzmann G, Engelhardt B, Kulic L, Suter T, Nitsch RM (2016) T-cell brain infiltration and immature antigen-presenting cells in transgenic models of Alzheimer's disease-like cerebral amyloidosis. Brain Behav Immun 54:211-225. https://doi.org/10.1016/j.bbi. 2016.02.009

26. Frisoni GB, Boccardi M, Barkhof F, Blennow K, Cappa S, Chiotis K, Démonet JF, Garibotto V, Giannakopoulos P, Gietl A, Hansson O, Herholz K, Jack CR, Nobili F, Nordberg A, Snyder HM,
Ten Kate M, Varrone A, Albanese E, Becker S, Bossuyt P, Carrillo MC, Cerami C, Dubois B, Gallo V, Giacobini E, Gold G, Hurst S, Lönneborg A, Lovblad KO, Mattsson N, Molinuevo JL, Monsch AU, Mosimann U, Padovani A, Picco A, Porteri C, Ratib O, Saint-Aubert L, Scerri C, Scheltens P, Schott JM, Sonni I, Teipel S, Vineis P, Visser PJ, Yasui Y, Winblad B (2017) Strategic roadmap for an early diagnosis of Alzheimer's disease based on biomarkers. Lancet Neurol 16:661-676. https://doi.org/10.1016/ S1474-4422(17)30159-X

27. Frontiñán-Rubio J, Sancho-Bielsa FJ, Peinado JR, LaFerla FM, Giménez-Llort L, Durán-Prado M, Alcain FJ (2018) Sex-dependent co-occurrence of hypoxia and $\beta$-amyloid plaques in hippocampus and entorhinal cortex is reversed by long-term treatment with ubiquinol and ascorbic acid in the $3 \times \mathrm{Tg}-\mathrm{AD}$ mouse model of Alzheimer's disease. Mol Cell Neurosci 92:67-81. https://doi.org/ 10.1016/j.men.2018.06.005

28. Fukumoto K, Mizoguchi H, Takeuchi H, Horiuchi H, Kawanokuchi J, Jin S, Mizuno T, Suzumura A (2014) Fingolimod increases brain-derived neurotrophic factor levels and ameliorates amyloid $\beta$-induced memory impairment. Behav Brain Res 268:88-93. https://doi.org/10.1016/j.bbr.2014.03.046

29. Giménez-Llort L, Arranz L, Maté I, De la Fuente M (2008) Gender-specific neuroimmunoendocrine aging in a triple-transgenic $3 \times \mathrm{Tg}-\mathrm{AD}$ mouse model for Alzheimer's disease and its relation with longevity. NeuroImmunoModulation 15:331-343. https://doi. org/10.1159/000156475

30. L Giménez-Llort Y García K Buccieri S Revilla C Suol R Cristofol C Sanfeliu 2010 Gender-specific neuroimmunoendocrine response to treadmill exercise in 3xTg-AD mice Int $\mathrm{J}$ Alzheimers Dis 2010 https://doi.org/10.4061/2010/128354

31. Healy LM, Sheridan GK, Pritchard AJ, Rutkowska A, Mullershausen F, Dev KK (2013) Pathway specific modulation of S1P1 receptor signalling in rat and human astrocytes. $\mathrm{Br} \mathrm{J}$ Pharmacol 169:1114-1129. https://doi.org/10.1111/bph.12207

32. Hemmati F, Dargahi L, Nasoohi S, Omidbakhsh R, Mohamed Z, Chik Z, Naidu M, Ahmadiani A (2013) Neurorestorative effect of FTY720 in a rat model of Alzheimer's disease: comparison with memantine. Behav Brain Res 252:415-421. https://doi.org/ 10.1016/j.bbr.2013.06.016

33. Heneka MT, Carson MJ, Khoury JE, Landreth GE, Brosseron F, Feinstein DL, Jacobs AH, Wyss-Coray T, Vitorica J, Ransohoff RM, Herrup K, Frautschy SA, Finsen B, Brown GC, Verkhratsky A, Yamanaka K, Koistinaho J, Latz E, Halle A, Petzold GC, Town T, Morgan D, Shinohara ML, Perry VH, Holmes C, Bazan NG, Brooks DJ, Hunot S, Joseph B, Deigendesch N, Garaschuk O, Boddeke E, Dinarello CA, Breitner JC, Cole GM, Golenbock DT, Kummer MP (2015) Neuroinflammation in Alzheimer's disease. Lancet Neurol 14:388-405. https://doi.org/10.1016/S14744422(15)70016-5

34. Heneka MT, Kummer MP, Stutz A, Delekate A, Saecker A, Griep A, Axt D, Remus A, Tzeng T, Gelpi E, Halle A, Korte M, Latz E, Golenbock D (2013) HHS public access 493:674-678. https:// doi.org/10.1038/nature11729.NLRP3

35. Hirata-Fukae C, Li HF, Hoe HS, Gray AJ, Minami SS, Hamada K, Niikura T, Hua F, Tsukagoshi-Nagai H, Horikoshi-Sakuraba Y, Mughal M, Rebeck GW, LaFerla FM, Mattson MP, Iwata N, Saido TC, Klein WL, Duff KE, Aisen PS, Matsuoka Y (2008) Females exhibit more extensive amyloid, but not tau, pathology in an Alzheimer transgenic model. Brain Res 1216:92-103. https:// doi.org/10.1016/j.brainres.2008.03.079

36. Hopperton KE, Mohammad D, Trépanier MO, Giuliano V, Bazinet RP (2018) Markers of microglia in post-mortem brain samples from patients with Alzheimer's disease: a systematic review. Mol Psychiatry 23:177-198. https://doi.org/10.1038/mp.2017.246

37. Janelsins MC, Mastrangelo MA, Oddo S, LaFerla FM, Federoff HJ, Bowers WJ (2005) Early correlation of microglial activation 
with enhanced tumor necrosis factor-alpha and monocyte chemoattractant protein-1 expression specifically within the entorhinal cortex of triple transgenic Alzheimer's disease mice. J Neuroinflammation 2:1-12. https://doi.org/10.1186/1742-2094-2-23

38. H Jęśko PL Wencel WJ Lukiw RP Strosznajder 2019 Modulatory effects of fingolimod (FTY720) on the expression of sphingolipid metabolism-related genes in an animal model of Alzheimer's disease MolNeurobiol https://doi.org/10.1007/s12035-018-1040-x

39. Kapadia M, Mian MF, Michalski B, Azam AB, Ma D, Salwierz P, Christopher A, Rosa E, Zovkic IB, Forsythe P, Fahnestock M, Sakic B (2018) Sex-dependent differences in spontaneous autoimmunity in adult 3xTg-AD mice. J Alzheimers Dis 63:1191-1205. https://doi.org/10.3233/JAD-170779

40. Karaca I, Tamboli IY, Glebov K, Richter J, Fell LH, Grimm MO, Haupenthal VJ, Hartmann T, Gräler MH, van Echten-Deckert G, Walter J (2014) Deficiency of sphingosine-1-phosphate lyase impairs lysosomal metabolism of the amyloid precursor protein. $\mathrm{J}$ Biol Chem 289:16761-16772. https://doi.org/10.1074/jbc.M113. 535500

41. Kinney JW, Bemiller SM, Murtishaw AS, Leisgang AM, Salazar AM, Lamb BT (2018) Inflammation as a central mechanism in Alzheimer's disease. Alzheimer's Dement Transl Res Clin Interv 4:575-590. https://doi.org/10.1016/j.trci.2018.06.014

42. Laurent C, Buée L, Blum D (2018) Tau and neuroinflammation: what impact for Alzheimer's disease and tauopathies? Biomed J 41:21-33. https://doi.org/10.1016/j.bj.2018.01.003

43. Laurent C, Dorothée G, Hunot S, Martin E, Monnet Y, Duchamp M, Dong Y, Légeron FP, Leboucher A, Burnouf S, Faivre E, Carvalho K, Caillierez R, Zommer N, Demeyer D, Jouy N, Sazdovitch V, Schraen-Maschke S, Delarasse C, Buée L, Blum D (2017) Hippocampal $\mathrm{T}$ cell infiltration promotes neuroinflammation and cognitive decline in a mouse model of tauopathy. Brain 140:184-200. https://doi.org/10.1093/brain/aww270

44. Lee JE, Kim SY, Jeong Y-M, Yun H-Y, Baek KJ, Kwon NS, Park K-C, Kim D-S (2011) The regulatory mechanism of melanogenesis by FTY720, a sphingolipid analogue. Exp Dermatol 20:237241. https://doi.org/10.1111/j.1600-0625.2010.01148.x

45. Leong YQ, Ng KY, Chye SM, Ling APK, Koh RY (2020) Mechanisms of action of amyloid-beta and its precursor protein in neuronal cell death. Metab Brain Dis 35:11-30. https://doi.org/10. 1007/s11011-019-00516-y

46. Low A, Mak E, Malpetti M, Passamonti L, Nicastro N, Stefaniak JD, Savulich G, Chouliaras L, Su L, Rowe JB, Markus HS, O’Brien JT (2021) In vivo neuroinflammation and cerebral small vessel disease in mild cognitive impairment and Alzheimer's disease. J Neurol Neurosurg Psychiatry 92:45-52. https://doi.org/10. 1136/jnnp-2020-323894

47. Malpetti M, Kievit RA, Passamonti L, Jones PS, Tsvetanov KA, Rittman T, Mak E, Nicastro N, Bevan-Jones WR, Su L, Hong YT, Fryer TD, Aigbirho FI, O'Brien JT, Rowe JB (2020) The prognostic role of microglia and tau PET in Alzheimer's disease. Alzheimer's Dement 16:1-2. https://doi.org/10.1002/alz.039817

48. Malpetti M, Kievit RA, Passamonti L, Simon Jones P, Tsvetanov KA, Rittman T, Mak E, Nicastro N, Richard Bevan-Jones W, Su L, Hong YT, Fryer TD, Aigbirhio FI, O’Brien T, Rowe JB (2020) Microglial activation and tau burden predict cognitive decline in Alzheimer's disease. Brain 143:1588-1602. https://doi.org/10. 1093/brain/awaa088

49. Mehta D, Jackson R, Paul G, Shi J, Sabbagh M (2017) Why do trials for Alzheimer's disease drugs keep failing? A discontinued drug perspective for 2010-2015. Expert Opin Investig Drugs 26:735-739. https://doi.org/10.1080/13543784.2017.1323868

50. Meno-Tetang, G.M.L., Li, H., Mis, S., Pyszczynski, N., Heining, P., Lowe, P., Jusko, W.J., 2006. Physiologically based pharmacokinetic modeling of FTY720 (2-Amino-2[2-(-4-octylphenyl)ethyl] propane-1,3-diol hydrochloride) in rats after oral and intravenous doses. Drug Metab. Dispos. 34, 1480 LP - 1487. https://doi.org/ 10.1124/dmd.105.009001

51. Merlini M, Kirabali T, Kulic L, Nitsch RM, Ferretti MT (2018) Extravascular CD3+ $\mathrm{T}$ cells in brains of Alzheimer disease patients correlate with tau but not with amyloid pathology: an immunohistochemical study. Neurodegener Dis 18:49-56. https:// doi.org/10.1159/000486200

52. Monsonego A, Zota V, Karni A, Krieger JI, Bar-Or A, Bitan G, Budson AE, Sperling R, Selkoe DJ, Weiner HL (2003) Increased $\mathrm{T}$ cell reactivity to amyloid beta protein in older humans and patients with Alzheimer disease. J Clin Invest 112:415-422. https://doi.org/10.1172/JCI18104

53. EJ Mufson KJ Oh SE Perez S Lagalwar L Vana L Binder 2010 Staging of Alzheimer's pathology in triple transgenic mice: a light and electron microscopic analysis Int J Alzheimers Dis 2010 https://doi.org/10.4061/2010/780102

54. Mullershausen F, Craveiro LM, Shin Y, Cortes-Cros M, Bassilana F, Osinde M, Wishart WL, Guerini D, Thallmair M, Schwab ME, Sivasankaran R, Seuwen K, Dev KK (2007) Phosphorylated FTY720 promotes astrocyte migration through sphingosine-1-phosphate receptors. J Neurochem 102:11511161. https://doi.org/10.1111/j.1471-4159.2007.04629.x

55. E Nichols CEI Szoeke SE Vollset N Abbasi F Abd-Allah J Abdela MTE Aichour RO Akinyemi F Alahdab SW Asgedom A Awasthi SL Barker-Collo BT Baune Y Béjot AB Belachew DA Bennett B Biadgo A Bijani MS Bin Sayeed C Brayne DO Carpenter F Carvalho F Catalá-López E Cerin JYJ Choi AK Dang MG Degefa S Djalalinia M Dubey EE Duken D Edvardsson M Endres S Eskandarieh A Faro F Farzadfar SM Fereshtehnejad E Fernandes I Filip F Fischer AK Gebre D Geremew M Ghasemi-Kasman EV Gnedovskaya R Gupta V Hachinski TB Hagos S Hamidi GJ Hankey JM Haro SI Hay SSN Irvani RP Jha JB Jonas R Kalani A Karch A Kasaeian YS Khader IA Khalil EA Khan T Khanna TAM Khoja J Khubchandani A Kisa K Kissimova-Skarbek M Kivimäki A Koyanagi KJ Krohn G Logroscino S Lorkowski M Majdan R Malekzadeh W März J Massano G Mengistu A Meretoja M Mohammadi M Mohammadi-Khanaposhtani AH Mokdad S Mondello G Moradi G Nagel M Naghavi G Naik LH Nguyen TH Nguyen YL Nirayo MR Nixon R Ofori-Asenso FA Ogbo AT Olagunju MO Owolabi S Panda-Jonas VM Passos d. A., Pereira, D.M., Pinilla-Monsalve, G.D., Piradov, M.A., Pond, C.D., Poustchi, H., Qorbani, M., Radfar, A., Reiner, R.C., Robinson, S.R., Roshandel, G., Rostami, A., Russ, T.C., Sachdev, P.S., Safari, H., Safiri, S., Sahathevan, R., Salimi, Y., Satpathy, M., Sawhney, M., Saylan, M., Sepanlou, S.G., Shafieesabet, A., Shaikh, M.A., Sahraian, M.A., Shigematsu, M., Shiri, R., Shiue, I., Silva, J.P., Smith, M., Sobhani, S., Stein, D.J., Tabarés-Seisdedos, R., Tovani-Palone, M.R., Tran, B.X., Tran, T.T., Tsegay, A.T., Ullah, I., Venketasubramanian, N., Vlassov, V., Wang, Y.P., Weiss, J., Westerman, R., Wijeratne, T., Wyper, G.M.A., Yano, Y., Yimer, E.M., Yonemoto, N., Yousefifard, M., Zaidi, Z., Zare, Z., Vos, T., Feigin, V.L., Murray, C.J.L., 2019 Global, regional, and national burden of Alzheimer's disease and other dementias, 1990-2016: a systematic analysis for the global burden of disease study 2016 Lancet Neurol 1888106 https://doi.org/10.1016/S14744422(18)30403-4

56. O'Sullivan C, Dev KK (2015) Galactosylsphingosine (psychosine)-induced demyelination is attenuated by sphingosine 1-phosphate signalling. J Cell Sci 128:3878-3887. https://doi.org/ $10.1242 /$ jcs. 169342

57. O'Sullivan S (2017) Sphingosine-1-phosphate receptor therapies: advances in clinical trials for CNS-related diseases. Neuropharmacology 113:597-607. https://doi.org/10.1016/J.NEUROPHARM. 2016.11.006 
58. O’Sullivan SA, Velasco-Estevez M, Dev KK (2017) Demyelination induced by oxidative stress is regulated by sphingosine 1-phosphate receptors. Glia 65:1119-1136. https://doi.org/10. 1002/glia.23148

59. Oddo S, Caccamo A, Shepherd JD, Murphy MP, Golde TE, Kayed R, Metherate R, Mattson MP, Akbari Y, LaFerla FM (2003) Triple-transgenic model of Alzheimer's disease with plaques and tangles: intracellular $\mathrm{A} \beta$ and synaptic dysfunction. Neuron 39:409-421. https://doi.org/10.1016/S0896-6273(03)00434-3

60. Osinde M, Mullershausen F, Dev KK (2007) Phosphorylated FTY720 stimulates ERK phosphorylation in astrocytes via S1P receptors. Neuropharmacology 52:1210-1218. https://doi.org/10. 1016/J.NEUROPHARM.2006.11.010

61. Parbo P, Ismail R, Sommerauer M, Stokholm MG, Hansen AK, Hansen KV, Amidi A, Schaldemose JL, Gottrup H, Brændgaard H, Eskildsen SF, Borghammer P, Hinz R, Aanerud J, Brooks DJ (2018) Does inflammation precede tau aggregation in early Alzheimer's disease? A PET study. Neurobiol Dis 117:211-216. https://doi.org/10.1016/j.nbd.2018.06.004

62. C Pösel K Möller J Boltze D-C Wagner G Weise 2016 Isolation and flow cytometric analysis of immune cells from the ischemic mouse brain J Vis Exp 53658 https://doi.org/10.3791/53658

63. Pritchard, A.J., Mir, A.K., Dev, K.K., 2014. Fingolimod attenuates splenocyte-induced demyelination in cerebellar slice cultures. PLoS One 9, e99444.

64. Rana A, Sharma S (2016) Mechanism of sphingosine-1-phosphate induced cardioprotection against I/R injury in diabetic rat heart: possible involvement of glycogen synthase kinase $3 \beta$ and mitochondrial permeability transition pore. Clin Exp Pharmacol Physiol 43:166-173. https://doi.org/10.1111/1440-1681.12516

65. Sheridan GK, Dev KK (2014) Targeting S1P receptors in experimental autoimmune encephalomyelitis in mice improves early deficits in locomotor activity and increases ultrasonic vocalisations. Sci Rep 4:1-6. https://doi.org/10.1038/srep05051

66. Sheridan GK, Dev KK (2012) S1P1 receptor subtype inhibits demyelination and regulates chemokine release in cerebellar slice cultures. Glia 60:382-392. https://doi.org/10.1002/glia.22272

67. Sterniczuk R, Antle MC, Laferla FM, Dyck RH (2010) Characterization of the 3xTg-AD mouse model of Alzheimer's disease: part 2. Behavioral and cognitive changes Brain Res 1348:149-155. https://doi.org/10.1016/j.brainres.2010.06.011

68. Stewart WF, Kawas C, Corrada M, Metter EJ (1997) Risk of Alzheimer's disease and duration of NSAID use. Neurology 48:626632. https://doi.org/10.1212/WNL.48.3.626

69. Stimmell AC, Baglietto-Vargas D, Moseley SC, Lapointe V, Thompson LM, LaFerla FM, McNaughton BL, Wilber AA (2019) Impaired spatial reorientation in the $3 \times \mathrm{Tg}-\mathrm{AD}$ mouse model of Alzheimer's disease. Sci Rep 9:1-12. https://doi.org/10.1038/ s41598-018-37151-z
70. Taipa R, Ferreira V, Brochado P, Robinson A, Reis I, Marques F, Mann DM, Melo-Pires M, Sousa N (2018) Inflammatory pathology markers (activated microglia and reactive astrocytes) in early and late onset Alzheimer disease: a post mortem study. Neuropathol Appl Neurobiol 44:298-313. https://doi.org/10.1111/nan. 12445

71. Takahashi RH, Nagao T, Gouras GK (2017) Plaque formation and the intraneuronal accumulation of $\beta$-amyloid in Alzheimer's disease. Pathol Int 67:185-193. https://doi.org/10.1111/pin.12520

72. Takasugi, N., Sasaki, T., Ebinuma, I., Osawa, S., Isshiki, H., Takeo, K., Tomita, T., Iwatsubo, T., 2013. FTY720/Fingolimod, a sphingosine analogue, reduces amyloid- $\beta$ production in neurons. PLoS One 8, e64050.

73. Tanzi RE (2012) The genetics of Alzheimer disease. Cold Spring Harb Perspect Med 2:1-10. https://doi.org/10.1101/cshperspect. a006296

74. Tian T, Zhang J, Zhu X, Wen S, Shi D, Zhou H (2017) FTY720 ameliorates renal fibrosis by simultaneously affecting leucocyte recruitment and TGF- $\beta$ signalling in fibroblasts. Clin Exp Immunol 190:68-78. https://doi.org/10.1111/cei.13003

75. Togo T, Akiyama H, Iseki E, Kondo H, Ikeda K, Kato M, Oda T, Tsuchiya K, Kosaka K (2002) Occurrence of T cells in the brain of Alzheimer's disease and other neurological diseases. J Neuroimmunol 124:83-92. https://doi.org/10.1016/S0165-5728(01) 00496-9

76. Weller, J., Budson, A., 2018. Current understanding of Alzheimer's disease diagnosis and treatment. F1000Research 7, 1-9. https://doi.org/10.12688/f1000research.14506.1

77. Yang JT, Wang ZJ, Cai HY, Yuan L, Hu MM, Wu MN, Qi JS (2018) Sex differences in neuropathology and cognitive behavior in APP/PS1/tau triple-transgenic mouse model of Alzheimer's disease. Neurosci Bull 34:736-746. https://doi.org/10.1007/ s12264-018-0268-9

78. Young K, Morrison H (2018) Quantifying microglia morphology from photomicrographs of immunohistochemistry prepared tissue using imagej. J Vis Exp 2018:1-9. https://doi.org/10.3791/57648

79. Zhang C, Wang Y, Wang D, Zhang J, Zhang F (2018) NSAID exposure and risk of Alzheimer's disease: an updated meta-analysis from cohort studies. Front Aging Neurosci 10:83. https://doi. org/10.3389/fnagi.2018.00083

80. Zhang YL, Xing RZ, Luo XB, Xu H, Chang RCC, Zou LY, Liu JJ, Yang XF (2016) Anxiety-like behavior and dysregulation of miR-34a in triple transgenic mice of Alzheimer's disease. Eur Rev Med Pharmacol Sci 20:2853-2862

Publisher's Note Springer Nature remains neutral with regard to jurisdictional claims in published maps and institutional affiliations. 